\title{
Below-and above ground biomass distribution of young Scots pines from plantations and natural stands
}

\author{
Distribución de la biomasa aérea y subterránea de árboles jóvenes \\ de plantaciones y bosque nativo de Pinus sylvestris
}

\author{
Ali Durkaya ${ }^{a}$, Birsen Durkaya ${ }^{\text {b* }}$, Şeyma Ulu Say ${ }^{c}$ \\ ${ }^{a}$ Bartin University, Faculty of Forestry, Forest Engineering, Department of Forest Management, \\ Ağdac1 Country, 74100, Bartin, Turkey. \\ *Corresponding author: ${ }^{\mathrm{b}}$ Bartin University, Faculty of Forestry, Forest Engineering, \\ Department of Forest Management, Ağdac1 Country, 74100, Bartin, Turkey, bdurkaya@bartin.edu.tr \\ ${ }^{\mathrm{c}}$ General Directorate of Forestry, Ankara, Turkey.
}

\begin{abstract}
SUMMARY
The belowground and aboveground biomass development of plantations and natural stands of young Scots pines (Pinus sylvestris) in the same habitat was modeled. 20 individuals having different diameters at breast-height were chosen from each group. Using the data obtained from those individuals, the biomass values of tree components (stem wood, stem bark, branch wood, branch bark, needle, stump wood, stump bark, root wood and root bark) were calculated. Furthermore, the relationships between the stem volume and tree components biomass were modeled. The portions of tree components weight in total weight were bilaterally examined. As a result of that analysis, it has been found that, although the total biomass development of young trees taken from plantations and natural stands followed a similar course, there were significant differences in the development of tree components.
\end{abstract}

Key words: Pinus sylvestris, biomass, dry matter partitioning.

\section{RESUMEN}

Se modeló la biomasa subterránea y aérea de bosques naturales y plantaciones de pino silvestre jóvenes (Pinus sylvestris) en un mismo hábitat. Fueron seleccionados 20 individuos de cada grupo que tenían diferentes diámetros a la altura del pecho. Utilizando los datos obtenidos de tales individuos, se calcularon los valores de biomasa de los componentes del árbol (madera del tronco, corteza del tronco, madera de las ramas, corteza de las ramas, acículas, madera del tocón, corteza del tocón, madera de raíz, corteza de la raíz). También se modelaron las relaciones entre el volumen del tronco y la biomasa de los componentes de los árboles. Se examinaron bilateralmente las porciones de pesos de los componentes del árbol en el peso total. Como resultado de este análisis se encontró que, a pesar que la biomasa total de los árboles jóvenes procedentes de bosques naturales y plantaciones siguieron un curso similar, hubo diferencias significativas entre los desarrollos de los componentes del árbol.

Palabras clave: Pinus sylvestris, biomasa, distribución de materia seca.

\section{INTRODUCTION}

Forest ecosystems provide multi-dimensional benefits from local to global scale. The data on tree biomass are necessary for many activities such as determining the forest productivity and carbon storage and carbon cycle among the global-scale benefits besides the bioenergy management and the estimation of inflammable matter in forest fires (De Miguel et al. 2014). Exact and accurate determination of the amount of carbon stored in forest ecosystems and the carbon changes is of gradually increasing importance for minimizing the effects of global carbon cycle, especially $\mathrm{CO}_{2}$ emissions. Measuring the carbon within the forests is also an obligation brought by The United
Nations Framework Convention on Climate Change (UNFCCC) and Kyoto Protocol (Brown 2002). All parties that signed the UNFCCC are under obligation of preparing, publishing and periodically updating the national inventories by using comparable methods for gas emissions with greenhouse effect and removals from land use change and forestry (Joosten et al. 2004). On the other hand, because carbon is becoming a valued product on the global market, estimating the amount of carbon stored in growing trees and harvested wood is important (McKinley et al. 2011, Coşkun and Gençay 2011).

Forest inventory data are considered as important resources since they provide more accurate carbon storage data and better reflect the regional heterogeneity (Brown 
and Schroeder 1999). Good Practice Guidance for LULU$\mathrm{CF}$ activities requires the calculation of carbon stock change by using objective, transparent and appropriate methods and projects determining and limiting the uncertainties in time (IPCC 2003). For these reasons, there is an increasing interest on completely and accurately determining the forest carbon stocks (Brown 2002).

Allometric equations allowing us to estimate the biomass and carbon from the sizes of trees are widely used tools in determining the biomass and carbon stocks (Ketterings et al. 2001, Blujdea et al. 2012, Aholoukpe et al. 2013). General biomass expansion factors (BEF's) do not provide sufficiently accurate estimations since they cannot adequately adopt to the biomass and carbon stocked on growing stock under local conditions. For this reason, the allometric models evaluating local inventory results provide more accurate and reliable results for estimating the biomass and carbon amounts.

Scots pine (Pinus sylvestris L.) is the tree species that has the widest range of distribution and highest economic value in Eurasia region. Its range of distribution extends from Spain in the west $\left(5^{\circ} \mathrm{W}\right)$ to Okhotsk sea in the east $\left(130^{\circ} \mathrm{E}\right)$, from Scandinavia in the north $\left(70^{\circ} \mathrm{N}\right)$ to Turkey in the south $\left(38^{\circ} \mathrm{N}\right)$ (Oleksyn et al. 2002). Because it covers 75 million $\mathrm{km}^{2}$ of area ( $24 \%$ of total forests in Europe), Scots pine is an important component in carbon budget of Europe (Stanners and Bourdeau 1995). Scots pine is one of the most common natural pine species of Turkey. As a sum of productive and non-productive areas, it covers a total of $1,479,648$ ha of land. This land area corresponds to $14 \%$ of the total forest area of Turkey (Anonymous 2014).

Significant portions of Scots pine forests of Turkey have been transformed into unproductive areas in time under human pressure. Those areas are being rapidly rehabilitated now. In case of sufficient quality of seed availability, natural regeneration is preferred in rehabilitation, while plantation is preferred in other cases. For this reason, the natural stands and plantation stands may exist together in some regions. Our study was carried out on both, plantations and natural stands, in such kind of a region. The hypothesis of the study is established as: there are differences in the distribution of biomass of tree components between the two groups. In this regard, we examined if there is a difference between aboveground and belowground biomass storage of young individuals of the same species that have been grown under the same habitat conditions but via different silvicultural regimes, and the direction and level of this difference, if any. Moreover, we aimed at developing useful allometric biomass models for individuals grown via two different silvicultural regimes. The objectives in this parallel are: a) To model the biomass development based on diameter at breast-height $\left(\mathrm{d}_{1.30}\right)$ and diameter at breast height - tree height $\left(\mathrm{d}_{1.30}-\mathrm{h}\right)$ in terms of tree components, for both groups. b) For both groups, to model the biomass development based on stem volume (v) in terms of tree components. c) By utilizing the developed models, to examine the biomass differences between two groups in terms of height and stem volume parameters through comparisons.

In literature research, we could not find any comparative study on young Scots pine individuals grown under the same habitat conditions but via different silvicultural regimes. Furthermore, this study draws attention of researchers and practitioners on the uncertainties, one of the obstacles on the principle of "accurate and exact determination" in biomass reports. Thus, it would be possible to understand the differences and make better biomass stock evaluations.

\section{METHODS}

Study area. The study area was chosen within the borders of Çerkeş Forest Enterprise located between $32^{\circ} 43^{\prime}-33^{\circ} 03^{\prime} \mathrm{E}$ and $40^{\circ} 49^{\prime}-40^{\circ} 38^{\prime}$ W (figure 1). Çerkeş Forest Enterprise is completely in central Anatolian climate and geographical region and in transition zone of Western Black Sea climate region and Central Anatolian climate region. For this reason, the climate can be summarized with harsher Black Sea climate (the mixture of Black Sea and continental climates). Summers are droughty and lightly rainy (rainier than continental climate) and winters are cold and rainy generally snowy. The mean temperature in January, which is the coldest month, is $-2.6^{\circ} \mathrm{C}$, while the mean temperature of July, considered as the hottest month, is $18.4{ }^{\circ} \mathrm{C}$. Mean annual precipitation level is $391 \mathrm{~mm}$, and most of that amount is observed in spring and winter seasons. The annual relative humidity is $68 \%$.

Experimental data. Pure young Scots pine stands were involved in this study. Of these two stand types examined in this study, altitude is $1,600 \mathrm{~m}$, exposure is north, and slope is between 0 and $20 \%$. Having 5 to $26 \mathrm{~cm}$ diameters at breast height, 20 individuals from a natural stand and 20 individuals from a plantation stand, a total of 40 individuals, were taken as sample trees. In the selection of sample trees, the following characteristic were considered as highly important: to be alive, to have strong crown and single stem and to have healthy appearance. The trees, whose diameters were measured, were cut at the closest point to the soil, and afterwards, the height of the tree was measured. Consequently, the branches of the cut sample trees were removed from the stem and divided into groups as thinner than $4 \mathrm{~cm}$ (no commercial value) and thick (commercially valuable) branches and then weighted. Although, since there was not sufficient number of samples, the branch values were reunited. And subsequently, samples were taken from both groups. The stem was divided into $2.05 \mathrm{~m}$ sections, and the bottom diameter and length of the tip part and the diameters at the end of the sections were measured in order to determine the stem volume. Each section was weighted and $5 \mathrm{~cm}$. thick stem samples were taken from the middle of these sections. Af- 


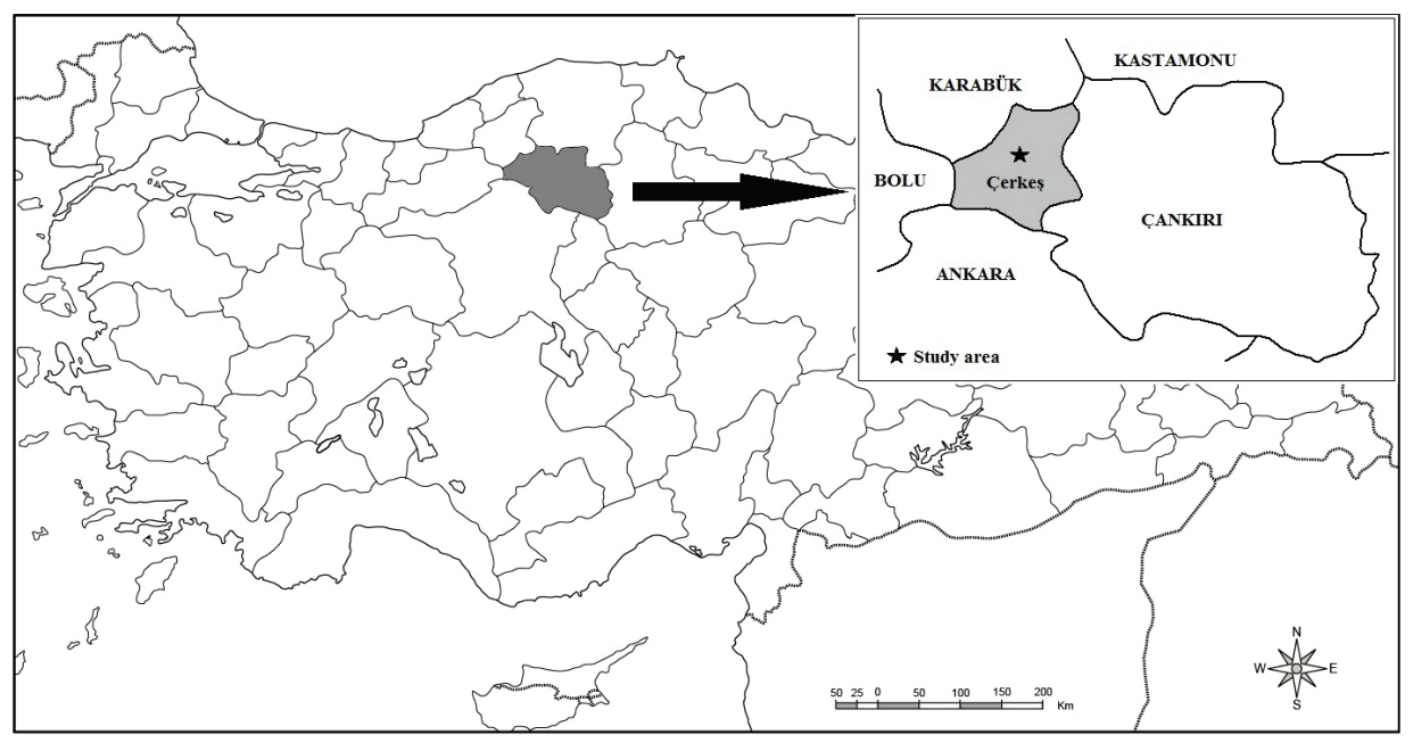

Figure 1. Study area.

Área de studio.

ter, the areas represented by each tree were determined, and excavated to the root depth with a digger. The roots were cleaned from soil, and the amount of coarse root $(>2 \mathrm{~mm}$ ) was determined. No work was done about the amount of fine root. Roots were divided into stump, thicker than $4 \mathrm{~cm}$ and thinner than $4 \mathrm{~cm}$, and then weighed. Samples were taken from each group. All samples were labeled and preserved in plastic bags. Samples were brought to the laboratory; needle-leaves were removed from the shoots, the woods were barked and fresh weight was determined. After air-dried, the samples were oven-dried at $65 \pm 3{ }^{\circ} \mathrm{C}$ until the weight stabilized and the final dry weight was determined.

Modeling biomass values. The biomass of tree components such as stem, branches, leaves, bark, coarse root and fine root are generally estimated using different allometric regression models based on DBH or DBH and $\mathrm{H}$ (Alberti et al. 2005, Soares and Schaeffer-Novelli 2005, Miksys et al. 2007, Peichl and Arain 2007, Guidi et al. 2008, Zewdie et al. 2009). In our study, different models were tested in the determination of biomass amounts as a function of $\mathrm{DBH}$ or DBH and H. Appropriate functions were chosen and used in the estimation of biomass. During the determination of the most appropriate functions, six different compliance measures were utilized. These measures are as follows: coefficient of determination $\left(\mathrm{R}^{2}\right), \mathrm{F}$ value, standard error of estimate $\left(\mathrm{S}_{\mathrm{e}}\right)$, mean deviation $(\bar{D})$, absolute mean deviation $(|\bar{D}|)$ and total error (TE (\%)). Average difference, average absolute difference, standard error, total error and average absolute error values should be small and coefficient of determination value should be large in order to obtain a reliable model.

\section{RESULTS}

Biomass equations. The biomass models that ideally represent the belowground and aboveground development of sample Scots pine individuals taken from young Scots pine stands established by natural regeneration or plantation are stated below. The models make it possible to estimate the biomass values of aboveground and belowground tree components from diameter at breast height $\left(d_{1.3}\right)$ and independent variables of diameter at breast height $\left(d_{1,3}\right)$ - tree height $(h)$. Since the amount of aboveground branches larger than $4 \mathrm{~cm}$ is unimportant, no discrimination was made.

Fourteen models were found to be suitable for estimating the biomass development from diameter at breast height $\left(d_{1,3}\right)$ of young Scots pine individuals from plantations and natural stands (table 1).

Of the individuals taken from natural stands, the aboveground components and the total belowground component have shown the highest level of relation with biomass relation through the logarithmic equations. Other parameters have provided successful results with linear and parabolic equations. While the models regarding the trees from natural stands showed higher level of relationship with aboveground components, the results found for the belowground components were opposite (while, for total aboveground, $\mathrm{R}^{2}=0.96$ in natural model, $\mathrm{R}^{2}=0.93$ in forestation model. For total belowground $\mathrm{R}^{2}=0.90$ in natural model, while $\mathrm{R}^{2}=0.92$ in forestation model.)

The models found to be suitable for estimating the biomass development from diameter at breast height $\left(d_{1.3}\right)$ and tree height $(h)$ of young Scots pine individuals from plantations and natural stands as independent variables are presented in tables 2 and 3 . 
Table 1. Models using the diameter at breast height $\left(d_{1.3}\right)$ as an independent variable. Modelos que utilizan el diámetro a la altura del pecho $\left(d_{l, 3}\right)$ como variable independiente.

\begin{tabular}{lll}
\hline \multicolumn{1}{c}{ Tree components } & \multicolumn{1}{c}{ Natural regeneration } & Plantation \\
\hline Stem wood & lny $=-2.2581+\left(2.2123 \operatorname{lnd}_{1.30}\right)(\mathrm{f}: 1.05)$ & $\mathrm{y}=4.8426+\left(0.0957 \mathrm{~d}_{1.30}{ }^{2}\right)$ \\
Stem bark & lny $=-3.8902+\left(1.9602 \operatorname{lnd}_{1.30}\right)(\mathrm{f}: 1.04)$ & $\mathrm{y}=-1.6326+\left(0.3638 \mathrm{~d}_{1.30}\right)$ \\
Branch wood & lny $=-8.4065+\left(3.4748 \operatorname{lnd}_{1.30}\right)(\mathrm{f}: 1.69)$ & $\mathrm{y}=-1.1187+\left(0.0486 \mathrm{~d}_{1.30}{ }^{2}\right)$ \\
Branch bark & $\mathrm{y}=-0.7235+\left(0.0099 \mathrm{~d}_{1.30}{ }^{2}\right)$ & $\mathrm{y}=0.754+\left(0.0104 \mathrm{~d}_{1.30}{ }^{2}\right)$ \\
Needle & $\ln \mathrm{y}=-4.3063+\left(2.2285 \operatorname{lnd}_{1.30}\right)(\mathrm{f}: 1.14)$ & $\mathrm{y}=6.053+\left(-1.1414 \mathrm{~d}_{1.30}\right)+\left(0.096 \mathrm{~d}_{1.30}{ }^{2}\right)$ \\
Crown & $\ln \mathrm{y}=-4.8726+\left(2.6494 \operatorname{lnd}_{1.30}\right)(\mathrm{f}: 1.19)$ & $\mathrm{y}=-2.0469+\left(0.1189 \mathrm{~d}_{1.30}{ }^{2}\right)$ \\
Total aboveground & $\ln \mathrm{y}=-2.1186+\left(2.2727 \operatorname{lnd}_{1.30}\right)(\mathrm{f}: 1.04)$ & $\mathrm{y}=3.5398+\left(0.2265 \mathrm{~d}_{1.30}{ }^{2}\right)$ \\
\hline Stump wood & $\mathrm{y}=-5.0985+\left(0.7379 \mathrm{~d}_{1.30}\right)$ & $\mathrm{y}=0.0094+\left(0.0198 \mathrm{~d}_{1.30}{ }^{2}\right)$ \\
Stump bark & $\mathrm{y}=-0.7444+\left(0.1275 \mathrm{~d}_{1.30}\right)$ & $\mathrm{y}=-0.3157+\left(0.0639 \mathrm{~d}_{1.30}\right)$ \\
Root wood $(>4 \mathrm{~cm})$ & $\mathrm{y}=-0.5864+\left(0.0216 \mathrm{~d}_{1.30}{ }^{2}\right)$ & $\mathrm{y}=5.8604+\left(-0.9292 \mathrm{~d}_{1.30}\right)+\left(0.0421 \mathrm{~d}_{1.30}{ }^{2}\right)$ \\
Root bark $(>4 \mathrm{~cm})$ & $\mathrm{y}=-0.1666+\left(0.005 \mathrm{~d}_{1.30}{ }^{2}\right)$ & $\mathrm{y}=0.8298+\left(-0.1291 \mathrm{~d}_{1.30}\right)+\left(0.0059 \mathrm{~d}_{1.30}{ }^{2}\right)$ \\
Root wood $(<4 \mathrm{~cm})$ & $\mathrm{y}=-0.5515+\left(0.1125 \mathrm{~d}_{1.30}\right)$ & $\mathrm{y}=0.02669+\left(0.006 \mathrm{~d}_{1.30}{ }^{2}\right)$ \\
Root bark $(<4 \mathrm{~cm})$ & $\mathrm{y}=-0.1997+\left(0.0496 \mathrm{~d}_{1.30}\right)$ & $\mathrm{y}=0.0516+\left(0.0013 \mathrm{~d}_{1.30}{ }^{2}\right)$ \\
Total belowground & $\ln \mathrm{y}=4.4971+\left(-28.6715 / \mathrm{d}_{1.30}\right)(\mathrm{f}: 1.19)$ & $\mathrm{y}=4.7934-\left(0.810 \mathrm{~d}_{1.30}\right)+\left(0.0705 \mathrm{~d}_{1.30}{ }^{2}\right)$ \\
\hline
\end{tabular}

$\ln$ : logarithm, $\mathrm{d}_{1.3}$ : diameter at breast height, f: correction factor.

Table 2. Aboveground biomass models that use diameter at breast height $\left(d_{1.3}\right)$ and tree height $(h)$ as independent variables. Modelos de biomasa aérea que utilizan el diámetro a la altura del pecho $\left(d_{l .3}\right)$ y la altura del árbol $(h)$ como variables independientes.

\begin{tabular}{|c|c|}
\hline Tree components & Natural regeneration \\
\hline Stem wood & $\ln y=-4.2619+\left(1.3188 \operatorname{lnd} d_{1.30}\right)+(1.8384 \operatorname{lnh})(f: 1.02)$ \\
\hline Stem bark & $\operatorname{lny}=-3.7746+\left(2.0117 \operatorname{lnd}_{1.30}\right)+(-0.106 \operatorname{lnh})(\mathrm{f}: 1.04)$ \\
\hline Branch wood & $\mathrm{y}=11.7913-\left(2.4208 \mathrm{~d}_{1.30}\right)+\left(0.0769 \mathrm{~d}_{1.30} \mathrm{~h}\right)+\left(0.0977 \mathrm{~d}_{1.30}{ }^{2}-\left(0.0008 \mathrm{~d}_{1.30}{ }^{2} \mathrm{~h}\right)\right.$ \\
\hline Branch bark & $\mathrm{y}=0.9075-\left(0.3572 \mathrm{~d}_{1.30}\right)+(0.0634 \mathrm{~h})+\left(0.0203 \mathrm{~d}_{1.30}^{2}\right)+\left(0.0176 \mathrm{~h}^{2}\right)$ \\
\hline Needle & $\mathrm{y}=5.8671-\left(1.2222 \mathrm{~d}_{1.30}\right)-(0.4615 \mathrm{~h})+\left(0.0659 \mathrm{~d}_{1.30}{ }^{2}\right)+\left(0.0914 \mathrm{~h}^{2}\right)$ \\
\hline Crown & $\mathrm{y}=-1.5226-\left(4.439 \mathrm{~d}_{1.30}\right)+(4.984 \mathrm{~h})+\left(0.2273 \mathrm{~d}_{1.30}^{2}\right)-\left(0.0567 \mathrm{~h}^{2}\right)$ \\
\hline Total aboveground & $\mathrm{y}=80.5963-\left(8.9552 \mathrm{~d}_{1.30}\right)-(13.0737 \mathrm{~h})+\left(0.4534 \mathrm{~d}_{1.30}{ }^{2}\right)+\left(1.2102 \mathrm{~h}^{2}\right)$ \\
\hline Tree components & Plantation \\
\hline Stem wood & $y=-2.8887+\left(3.0115 d_{1.30}\right)-(4.9743 h)+\left(0.4228 h^{2}\right)$ \\
\hline Stem bark & $\mathrm{y}=0.1662+\left(0.2755 \mathrm{~d}_{1.30}\right)-(0.5519 \mathrm{~h})+\left(0.0029 \mathrm{~d}_{1.30}^{2}\right)+\left(0.0502 \mathrm{~h}^{2}\right)$ \\
\hline Branch wood & $\mathrm{y}=-10.3673-\left(0.3725 \mathrm{~d}_{1.30}\right)+(3.2391 \mathrm{~h})+\left(0.0546 \mathrm{~d}_{1.30}^{2}\right)-\left(0.106 \mathrm{~h}^{2}\right)$ \\
\hline Branch bark & $\mathrm{y}=-2.7972+\left(0.1177 \mathrm{~d}_{1.30}\right)+(0.4278 \mathrm{~h})+\left(0.0038 \mathrm{~d}_{1.30}^{2}\right)+\left(0.0084 \mathrm{~h}^{2}\right)$ \\
\hline Needle & $\mathrm{y}=7.1799-\left(0.5205 \mathrm{~d}_{1.30}\right)-(2.0356 \mathrm{~h})+\left(0.0764 \mathrm{~d}_{1.30}{ }^{2}\right)+\left(0.1691 \mathrm{~h}^{2}\right)$ \\
\hline Crown & $\mathrm{y}=-5.9846-\left(0.7753 \mathrm{~d}_{1.30)}+(1.6313 \mathrm{~h})+\left(0.1349 \mathrm{~d}_{1.30}{ }^{2}\right)-\left(0.0031 \mathrm{~h}^{2}\right)\right.$ \\
\hline Total aboveground & $\mathrm{y}=-8.707+\left(2.5117 \mathrm{~d}_{1.30}\right)-(3.8949 \mathrm{~h})+\left(0.1378 \mathrm{~d}_{1.30}^{2}\right)+\left(0.4699 \mathrm{~h}^{2}\right)$ \\
\hline
\end{tabular}

ln: logarithm, $\mathrm{d}_{1.3}$ : diameter at breast height, h: tree height, f: correction factor. 
Table 3. Belowground biomass models that use diameter at breast height $\left(d_{1.3}\right)$ and tree height $(h)$ as independent variables.

Modelos de biomasa subterránea que utilizan diámetro a la altura del pecho $\left(d_{1.3}\right)$ y la altura del árbol $(h)$ como variables independientes.

\begin{tabular}{|c|c|}
\hline Tree components & Natural regeneration \\
\hline Stump wood & $\mathrm{y}=7.2732-\left(0.3336 \mathrm{~d}_{1.30}\right)-(1.7935 \mathrm{~h})+\left(0.0202 \mathrm{~d}_{1.30}{ }^{2}\right)+\left(0.1458 \mathrm{~h}^{2}\right)$ \\
\hline Stump bark & $y=0.5063+\left(0.2102 d_{1.30}\right)-(0.4075 h)-\left(0.0037 d_{1.30}^{2}\right)+\left(0.0234 h^{2}\right)$ \\
\hline Root wood $(>4 \mathrm{~cm})$ & $\mathrm{y}=44.8008+\left(1.129 \mathrm{~d}_{1.30}\right)-(10.8207 \mathrm{~h})+\left(0.0231 \mathrm{~d}_{1.30}^{2}\right)+\left(0.5431 \mathrm{~h}^{2)}\right.$ \\
\hline Root bark $(>4 \mathrm{~cm})$ & $\mathrm{y}=5.4944+\left(0.0593 \mathrm{~d}_{1.30}\right)-(1.3008 \mathrm{~h})+\left(0.0008 \mathrm{~d}_{1.30}^{2}\right)+\left(0.0705 \mathrm{~h}^{2}\right)$ \\
\hline Root wood $(<4 \mathrm{~cm})$ & $\mathrm{y}=0.2915-\left(0.1614 \mathrm{~d}_{1.30}\right)+(0.1783 \mathrm{~h})+\left(0.006 \mathrm{~d}_{1.30}^{2}\right)+\left(0.0031 \mathrm{~h}^{2}\right)$ \\
\hline Root bark $(<4 \mathrm{~cm})$ & $y=-0.1272-\left(0.0509 d_{1.30}\right)+(0.2247 h)+\left(0.0016 d_{1.30}^{2}\right)-\left(0.0034 h^{2}\right)$ \\
\hline Total belowground & $\mathrm{y}=37.1265+\left(0.2256 \mathrm{~d}_{1.30}\right)-(9.6165 \mathrm{~h})+\left(0.018 \mathrm{~d}_{1.30}{ }^{2}\right)+\left(0.6027 \mathrm{~h}^{2}\right)$ \\
\hline Tree components & Plantation \\
\hline Stump wood & $\mathrm{y}=-1.0774+\left(0.3149 \mathrm{~d}_{1.30}\right)-(0.567 \mathrm{~h})+\left(0.0091 \mathrm{~d}_{1.30}^{2}\right)+\left(0.0589 \mathrm{~h}^{2}\right)$ \\
\hline Stump bark & $y=-0.0741+\left(0.1069 d_{1.30}\right)-(0.2084 h)\left(-0.0013 d_{1.30}^{2}\right)+\left(0.0175 h^{2}\right)$ \\
\hline Root wood $(>4 \mathrm{~cm})$ & $y=6.0084-\left(0.9784 d_{1.30}\right)+\left(0.0024 d_{1.30} h\right)+\left(0.046 d_{1.30}^{2}\right)-\left(0.0003 d_{1.30}^{2} h\right)$ \\
\hline Root bark $(>4 \mathrm{~cm})$ & $\mathrm{y}=1.3348-\left(0.1913 \mathrm{~d}_{1.30}\right)+(0.2737 \mathrm{~h})+\left(0.0074 \mathrm{~d}_{1.30}^{2}\right)+\left(0.017 \mathrm{~h}^{2}\right)$ \\
\hline Root wood $(<4 \mathrm{~cm})$ & $\mathrm{y}=0.017-\left(0.1631 \mathrm{~d}_{1.30}\right)+(0.2856 \mathrm{~h})+\left(0.0105 \mathrm{~d}_{1.30}{ }^{2}\right)-\left(0.0138 \mathrm{~h}^{2}\right)$ \\
\hline Root bark $(<4 \mathrm{~cm})$ & $\mathrm{y}=0.0712-\left(0.0098 \mathrm{~d}_{1.30}\right)+(0.0031 \mathrm{~h})+\left(0.0015 \mathrm{~d}_{1.30}{ }^{2}\right)+\left(0.0008 \mathrm{~h}^{2}\right)$ \\
\hline Total belowground & $\mathrm{y}=0.1472-\left(0.8139 \mathrm{~d}_{1.30}\right)+(0.9186 \mathrm{~h})+\left(0.0666 \mathrm{~d}_{1.30}{ }^{2}\right)-\left(0.016 \mathrm{~h}^{2}\right)$ \\
\hline
\end{tabular}

ln: logarithm, $\mathrm{d}_{1.3}$ : diameter at breast height, h: tree height.

Stem wood and stem bark biomass development of individuals taken from natural stands have shown the highest level of relations with logarithmic equations. Other parameters have provided successful results with parabolic equations.

The biomass development of aboveground and belowground components of individuals taken from natural stands and forestation stands have shown the highest level of relationship with parabolic equations. No statistically significant difference was found between the models regarding the aboveground tree components taken from natural stands and the models regarding the aboveground tree components taken from forestation stands. But, for belowground components, the model regarding the forestations has shown higher relationship (for total aboveground; $\mathrm{R}^{2}=0.95$ in natural model and $\mathrm{R}^{2}=0.95$ in forestation model. For total belowground; $\mathrm{R}^{2}=0.88$ in natural model, and $\mathrm{R}^{2}=0.94$ in forestation model.)

As seen in figure 2, there are higher values in stem weight in natural stands. Although, the individuals taken from plantation stands are superior in terms of branch and needle weight. Again, compared with individuals having diameter at breast height larger than $15 \mathrm{~cm}$, the individuals taken from natural stands were found to be superior. Although the tree components show different values, it is seen that total aboveground and total tree weight are in balance.
The equations presenting the relationships between biomass of tree components and stem volume (v) of young Scots pine individuals are shown in table 4.

Considering the models showing the relationships between biomass of tree components, it was observed that higher level of relationships were found with individuals taken from natural stands in proportion to those taken from forestation stands (except for the belowground). Stem volume - biomass relations have followed a linear course for all components. In figure 3 , the volume-biomass relations of young Scots pine individuals taken from plantations and natural stands are comparatively presented, regarding tree components.

Regarding stem volume/stem weight relationship, a relation in favor of individuals taken from natural regeneration stands is observed, while the individuals taken from plantation stands were found to have higher volume/ weight values. Especially in branch and needle weights, a significant difference favoring plantation stands draws attention.

In our study, the biomass ratios of components determined via allometric models developed by using samples taken from plantations and natural stands are shown in table 5 . The results are presented in accordance with $5 \mathrm{~cm}$ of diameter intervals. 

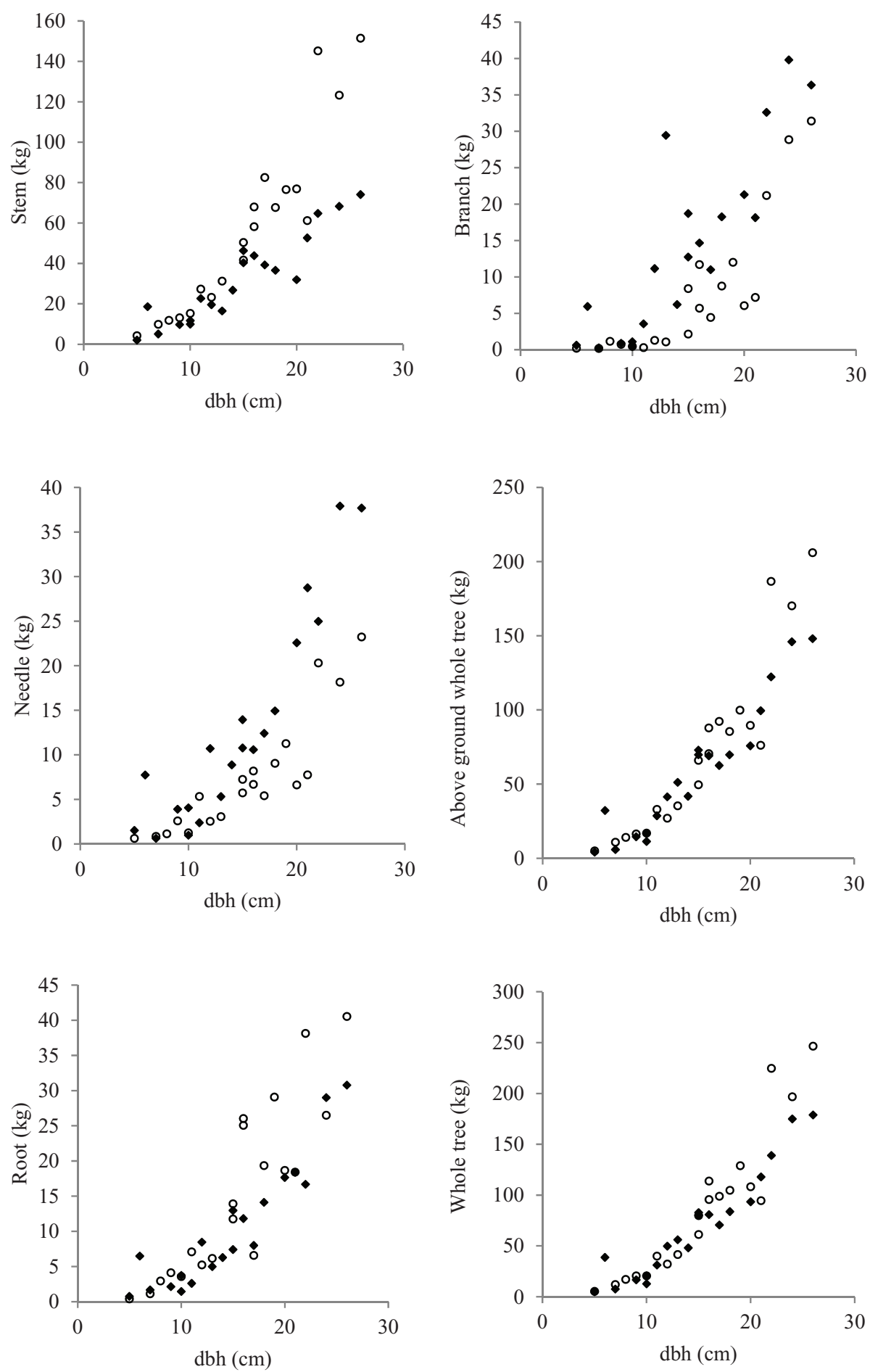

o Natural • Plantation

Figure 2. Diameter at breast height and biomass development of young Scots pine individuals from natural regeneration and plantation stands.

Diámetro a la altura del pecho y evolución de la biomasa de los individuos jóvenes de pino silvestre de regeneración de rodales naturales y plantación. 

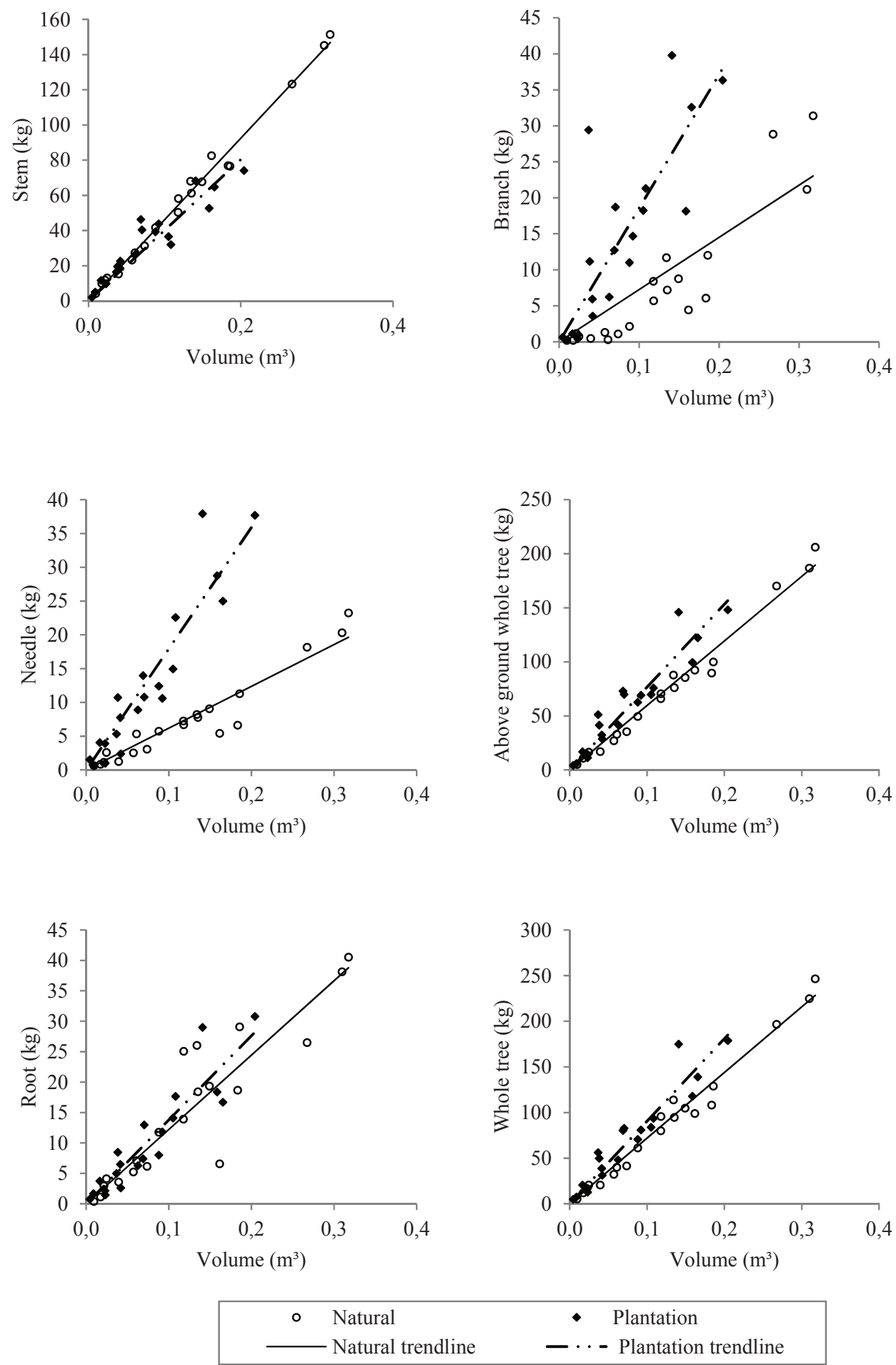

Figure 3. Volume-biomass relations of young Scots pine individuals taken from plantations and natural stands.

Relaciones del volumen y la biomasa de los individuos jóvenes de pino silvestre de bosques naturales y plantaciones. 
Table 4. Relationships between stem volume and biomass of tree components.

Relaciones entre el volumen de madera y la biomasa de los componentes de los árboles.

\begin{tabular}{|c|c|c|c|c|}
\hline \multirow{2}{*}{ Tree components } & \multicolumn{2}{|c|}{ Natural } & \multicolumn{2}{|c|}{ Plantation } \\
\hline & & $\mathrm{R}^{2}$ & & $\mathrm{R}^{2}$ \\
\hline Stem & $\mathrm{y}=462.59(\mathrm{v})$ & 0.99 & $\mathrm{y}=401.8(\mathrm{v})$ & 0.87 \\
\hline Branch & $\mathrm{y}=72.521(\mathrm{v})$ & 0.78 & $\mathrm{y}=185.6(\mathrm{v})$ & 0.67 \\
\hline Needle & $\mathrm{y}=61.914(\mathrm{v})$ & 0.91 & $\mathrm{y}=179.53(\mathrm{v})$ & 0.87 \\
\hline Above-ground & $\mathrm{y}=597.03(\mathrm{v})$ & 0.98 & $\mathrm{y}=766.94(v)$ & 0.90 \\
\hline Below-ground & $\mathrm{y}=122.22(\mathrm{v})$ & 0.83 & $\mathrm{y}=138.19(\mathrm{v})$ & 0.85 \\
\hline Whole tree & $\mathrm{y}=719.25(\mathrm{v})$ & 0.98 & $\mathrm{y}=905.12(\mathrm{v})$ & 0.90 \\
\hline
\end{tabular}

v: stem volume.

Table 5. Distribution of biomass amounts of various diameters among tree components according to the models based on diameter at breast height.

Distribución de las cantidades de biomasa de árboles de diversos diámetros entre sus componentes, de acuerdo con los modelos basados en el diámetro a la altura del pecho.

\begin{tabular}{|c|c|c|c|c|c|c|c|c|c|c|c|c|}
\hline \multirow{3}{*}{$\begin{array}{c}\text { Tree } \\
\text { components }\end{array}$} & \multicolumn{4}{|c|}{$\mathrm{d}_{1.30}=15 \mathrm{~cm}$} & \multicolumn{4}{|c|}{$\mathrm{d}_{1.30}=20 \mathrm{~cm}$} & \multicolumn{4}{|c|}{$\mathrm{d}_{1.30}=25 \mathrm{~cm}$} \\
\hline & \multicolumn{2}{|c|}{ Natural } & \multicolumn{2}{|c|}{ Plantation } & \multicolumn{2}{|c|}{ Natural } & \multicolumn{2}{|c|}{ Plantation } & \multicolumn{2}{|c|}{ Natural } & \multicolumn{2}{|c|}{ Plantation } \\
\hline & $\mathrm{kg}$ & $\%$ & $\mathrm{~kg}$ & $\%$ & $\mathrm{~kg}$ & $\%$ & $\mathrm{~kg}$ & $\%$ & $\mathrm{~kg}$ & $\%$ & $\mathrm{~kg}$ & $\%$ \\
\hline Stem & 48.13 & 64.47 & 30.2 & 47.93 & 90.39 & 65.19 & 48.77 & 43.96 & 147.41 & 66.43 & 72.12 & 41.51 \\
\hline Branch & 6.11 & 8.18 & 12.91 & 20.49 & 15.76 & 11.36 & 23.24 & 20.95 & 32.66 & 14.72 & 36.51 & 21.01 \\
\hline Needle & 6.42 & 8.60 & 10.53 & 16.71 & 12.19 & 8.79 & 21.62 & 19.48 & 20.05 & 9.03 & 37.52 & 21.59 \\
\hline Aboveground & 58.86 & 78.84 & 54.5 & 86.50 & 113.18 & 81.63 & 94.13 & 84.85 & 187.95 & 84.71 & 145.1 & 83.53 \\
\hline Belowground & 15.79 & 21.15 & 8.51 & 13.50 & 25.47 & 18.36 & 16.79 & 15.13 & 33.93 & 15.29 & 28.61 & 16.46 \\
\hline
\end{tabular}

\section{DISCUSSION}

Although the most accurate method is to determine the biomass of a tree by directly cutting and weighing it on field, it is a very time-consuming and destructive method (Ketterings et al. 2001). The use of allometric relationships in determining biomass is a widely-preferred method that is non-destructive and indirect, because it takes less time and is cheaper than direct measurements (St. Clair 1993). In this study, by using the data obtained from tree samples taken from plantations and natural stands, the biomass amounts by the tree components from both stands were modelled via allometric relations. Moreover, the relations between stem volumes and biomass of components were shown.

Comparing the individuals having the same diameter at breast height, it was found that the tree height in natural stands was higher and consequently the stem weight is also higher, while the weight of needles and branches of the trees in plantation stands was higher. Again, in terms of coarse root weight, it was found that the values obtained from individuals from natural stands were higher.
Although the components had different weights, it was determined that total aboveground and total tree weight were in balance. This is expected for individuals grown under the same habitat conditions but different growing conditions. That is to say; since individuals taken from plantation stands having sufficient area compete less for light, water and nutrients in proportion to those grown in natural stands, they are shorter and their coarse root development is worse. On the other hand, as a result of receiving more light, the branch and needle development is better.

Although IPCC recommends using forest inventory in determining carbon stock changes, generally forest inventories focus on wood volume due to economic reasons and do not contain data regarding determination of biomass (Coomes et al. 2002). In forestry practice in Turkey, stand definitions are made according to tree species, diameter level and crown closure. Tree diameter levels are named as "development stages", and represent a very wide diameter range. Hence, utilizing biomass and carbon models only by using tree diameter or tree diameter and height is not possible when only the data in forest management plans 
are used. For this reason, additional studies are needed. In our study, it becomes possible to reliably reach biomass values by using only the plant stem volume, which is the most useful parameter in forest management plans, without any need for additional operations.

Given the stem volume-biomass relations of individuals from both groups (figure 2), it is seen that natural stands are superior only in stem weight, while plantation stands are superior in all other components and total amounts. Comparing individuals having the same diameter at breast height but from different groups, although they have similar total biomass values, the portion of stem volume in total value for individuals taken from plantation stands is lower than that of individuals from natural stands. This proportional lowness causes the result regarding stem volume with biomass.

Some previous studies and the evaluations on their results are presented below. Xiao and Ceulemans (2004) have determined the biomass retaining capacity of 10 year-old young Scots pine individuals and stands via allometric relations. Mean diameter at breast height is 7.16 $\mathrm{cm}$ and height varies between 4.5 and $5.6 \mathrm{~m}$. Ilvesniemi and Liu (2001) have determined the biomass distribution of a young Scots pine stand established with a plantation. Mean height is $10.2 \mathrm{~m}$. Xiao et al. (2003) have examined the above and belowground biomass and net primary products of a plantation stand consisting of 73 year old Scots pine. Helmisaari et al. (2002) have sampled from 15,35 and 100 year- old stands among natural stands, and afterwards determined the biomass. The ratios of biomass for tree components in those studies are shown in table 6 .

Our hypothesis was confirmed by the study results. As seen in tables 5 and 6 , distribution of total biomass of tree components of the same species significantly varies in the same habitat and under different silvicultural regimes. For example, the difference between $25 \mathrm{~cm}$ diameter stem biomass of individuals from both groups reaches up to about $25 \%$ of the total tree biomass.

As seen in the natural stand part of our study; the portion of stem biomass in total biomass increases but others decrease as the individual becomes older. Although, for individuals taken from plantation stands, the course is in the opposite direction; while the portion of stem biomass in total biomass decreases, the others increase. This is contrary to the expected situation. It can be said that this situation is caused by the formation of thicker branch and plenty of needle due to no competition for light. Similarly, since there was no competition for water and nutrients at the beginning in plantation stands, the root development is observed to have increased with the increase in diameter.

In carbon storage reports of forest ecosystems, calculation of carbon stock changes by using objective, transparent and appropriate methods is requested, and determining the uncertainties and minimizing them in time are projected (IPCC 2003). Determining the stored biomass amounts completely and accurately is of gradually increasing importance for decreasing the effects of global carbon cycle, especially $\mathrm{CO}_{2}$ emissions (Brown 2002, Zhao and Zhou 2005). The calculations made using Biomass Expansion Factors yield $17 \%$ more than those based on models (Durkaya et al. 2014). This situation contradicts with the principle of "complete and exact determination" that is expected from the calculations. For this reason, developing and using regional models is of significant importance. The information most easily obtained from the forest inventory and management plans is the standing stem volume. Consequently, the regional models to be developed should allow estimation of aboveground and belowground biomass and carbon values and the portions of them removed from forest ecosystem because of economic value and those left in forest ecosystem because of economic insignificance by using the standing stem volume data.

\section{CONCLUSIONS}

To determine the level of biomass stored in forests, rather than starting from general consents, it is a better approach to carry out separate studies for each species. But, as seen above, the significant variations may be seen in different habitats, even in the same species. In our study, the biomass of young Scots pine individuals in the same habitat that have grown under different conditions is comparatively examined. Although the total biomass values

Table 6. Distribution of biomass through tree components in some studies.

Distribución de la biomasa a través de los componentes de árboles en algunos estudios.

\begin{tabular}{lcccccc}
\hline & $\begin{array}{c}\text { Xiao and Ceulemans } \\
\text { Tree components }\end{array}$ & $\begin{array}{c}\text { Ilvesniemi and Liu } \\
\text { (2001) }\end{array}$ & $\begin{array}{c}\text { Xiao et al. } \\
(2003)\end{array}$ & \multicolumn{3}{c}{$\begin{array}{c}\text { Helmisaari } \text { et al. } \\
\text { (2002) }\end{array}$} \\
\cline { 2 - 5 } & Belgium & Finland & Belgium & \multicolumn{3}{c}{ Finland } \\
\cline { 5 - 7 } & & & & Sapling & Pole stage & Mature \\
\hline Stem (\%) & 33.9 & 60.8 & 74.4 & 32.1 & 53.8 & 72.2 \\
Branch (\%) & 25 & 13.2 & 10.1 & 33.8 & 16.6 & 10.4 \\
Needle (\%) & 22 & 7.4 & 2 & 8.8 & 8.6 & 4.2 \\
Total belowground (\%) & 19.1 & 18.3 & 12.6 & 25.3 & 21 & 13.2 \\
\hline
\end{tabular}


coursed closely, differences emerged in distribution of biomass across the tree components. There are significant differences especially among the stem volume-biomass relations of individuals taken from natural and plantation stands. These differences among the biomass levels of young individuals of the same species grown under different silvicultural conditions but in the same habitat have shown that the method for completely and exactly determining the biomass stocks and changes in these stocks in forest ecosystems is possible by developing regional models rather than using general methods.

\section{REFERENCES}

Aholoukpe H, Dubos B, Flori A, Deleporte P, Amajdi G, Choette JL, Blavet D. 2013. Estimating above ground biomass of oil palm: Allometric equations for estimating frond biomass. Forest Ecology And Management 292: 122-129.

Alberti G, Candido P, Peressotti A, Turco S, Piussi P, Zerbi G. 2005. Aboveground biomass relationships for mixed ash (Fraxinus excelsior L. and Ulmus glabra Hudson) stands in Eastern Prealps of Friuli Venezia Giulia (Italy). Annals of Forest Science 62(8): 831-836. DOI: 10.1051/forest.2005089.

Anonymous. 2014. Türkiye Orman Varlığı. General Direction Of Forestry Publications No: 17/115, Ankara.

Blujdea VNB, R Pilli, I Dutca, L Ciuvat, IV Abrudan. 2012. Allometric biomass equations for young broadleaved trees in plantations in Romania. Forest Ecology and Management 264: $172-184$.

Brown S. 2002. Measuring carbon in forests: current status and future challenges. Environmental Pollution 116(3): 363-372.

Brown SL, PE Schroeder. 1999. Spatial patterns of aboveground production and mortality of wood biomass for eastern U.S. Forests. Ecological Appilications 9(3): 968-980.

Coomes DA, RB Allen, NA Scott, C Goulding, P Beets. 2002. Designing systems to monitor carbon stocks in forests and shrublands. Forest Ecology and Management 164(1-3): 89-108.

Coşkun A, G Gençay. 2011. Kyoto Protocol and "deforestation" A legal analysis on Turkish environment and forest legislation. Forest Policy and Economics 13(5): 366-377.

De Miguel S, L Mehtatalo, A Durkaya. 2014. Developing generalized, calibratable, mixed-effects meta-models for largescale biomass predictions. Canadian Journal of Forest Research 44(6): 648-656.

Durkaya B, T Varol, A Durkaya. 2014. Determination of carbon stock changes: Biomass models or biomass expansion factors. Fresenius Environmental Bulletin 23(3): 774-781.

Guidi W, Piccioni E, Ginanni M, Bonari E. 2008. Bark content estimation in poplar (Populus deltoides L.) short-rotation coppice in Central Italy. Biomass Bioenergy 32: 518-524. DOI:10.1016/j.biombioe.2007.11.012.

Helmisaari HS, K Makkonen, S Kellomaki, Valtonen E, Malkönen E. 2002. Below- and above-ground biomass, production and nitrogen use in Scots pine stands in eastern Fin- land. Forest Ecology and Management 165(1-3): 317-326.

Ilvesniemi H, C Liu. 2001. Biomass distribution in a young Scots pine stand. Boreal Environment Research 6: 3-8.

IPCC (Intergovernmental Panel on Climate Change). 2003. Good practice guidance for land use, land-use change and forestry. Institute For Global Environmental Strategies (IGES), Japan.

Joosten R, J Schumacher, W Christian, Schulte A. 2004. Evaluating tree carbon predictions for beech (Fagus sylvatica L.) in Western Germany. Forest Ecology and Management 189(1-3): 87-96.

Ketterings QM, R Coe, M Noordwijk, Y Ambagau, CA Palm. 2001. Reducing uncertainty in the use of allometric biomass equations for predicting above-ground tree biomass in mixed secondary forests. Forest Ecology and Management 146: 199-209.

McKinley DC, MG Ryan, RA Birdsey, CP Giardina, LS Health, RA Houghton, RB Jackson, JF Morrison, BC Murray, DE Pataki, KE Skog. 2011. A synthesis of curresnt knowledge on forests and carbon storage in the United States, Ecological Applications 21(6): 1902-1924.

Miksys V, I Varnagiryte-Kabasinskiene, I Stupak, K Armolaitis, M Kukkola, J Wojcik. 2007. Above-ground Biomass Functions for Scots Pine in Lithuania. Biomass Bioenergy 31(10): 685-692. DOI:10.1016/j.biombioe.2007.06.013.

Oleksyn J, PB Reich, R Zytkowiak, P Karolewski, MG Tjoelker. 2002. Needle nutrients in geographically diverse Pinus sylvestris L. populations. Annals of Forest Science 59(1): 1-18.

Peichl M, Arain MA. 2007. Allometry and partitioning of aboveand belowground tree biomass in an age-sequence of white pine forests. Forest Ecology and Management 253(1-3): 68-80. DOI:10.1016/j.foreco.2007.07.003.

Soares MLG, Y Schaeffer-Novelli. 2005. Above-ground biomass of mangrove species. I. Analysis of models. Estuarine, Coastal and Shelf Science 65: 1-18.

St. Clair JB. 1993. Family differences in equations for predicting biomass and leaf area in Douglas fir (Pseudotsuga menziesii var. menziesii). Forest Science 39(4): 743-755.

Stanners D, P Bourdeau. 1995. Europe's environment-the Dobris assessment. Copenhagen, Denmark. European Environment Agency. $676 \mathrm{p}$.

Xiao CW, J Curiel Yuste, IA Janssens, P Roskams, L Nachtergale, A Carrara, BY Sanchez, R Ceulemans. 2003. Above- and belowground biomass and net primary production in a 73-yearold Scots pine forest. Tree Physiology 23(8): 505-516.

Xiao CW, R Ceulemans. 2004. Allometric relationships for below- and abovegroundbiomass of young Scots pines. Forest Ecology and Management 203: 177-186.

Zewdie M, M Olsson, T Wervijst. 2009. Above-ground biomass production and allometric relations of Eucalyptus globulus Labill. Coppice plantations along a chronosequence in the central highlands of Ethiopia. Biomass Bioenergy 33(3): 421428. DOI:10.1016/j.biombioe.2008.08.007.

Zhao M, G Zhou. 2005. Estimation of biomass and net primary productivity of major planted forests in China based on forest inventory data, Forest Ecology and Management 207(3): 295-313. 